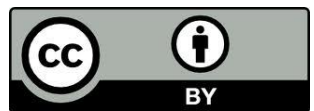

\title{
PADRE FRANCISCO OZAMIZ, UM INTELECTUAL DA IMPRENSA CATÓLICA POPULAR (1909-1929)
}

\section{Priest Francisco Ozamiz, an intellectual of the popular Catholic press (1909-1929)}

\author{
Marcos Gonçalves \\ Doutor em História. Professor Adjunto II \\ Programa de Pós-Graduação em História (PPGHIS) \\ Universidade Federal do Paraná \\ e-mail: paideia_mg@yahoo.com.br
}

RESUMO: O artigo analisa e descreve parte da trajetória intelectual do padre claretiano Francisco Ozamiz entre os anos de 1909 a 1929, no âmbito do periódico católico Ave Maria, publicado em São Paulo, mas de alcance nacional. As ações de Ozamiz no projeto de vitalização da imprensa católica estão associadas a uma demanda de significativa amplitude da Igreja católica no Brasil entre o final do século XIX e as duas primeiras décadas do século XX: expandir a influência do periodismo católico, estabelecer uma efetiva agenda crítica ao Estado laico, desdobrando tal agenda para o campo de competição com outras denominações religiosas e para a esfera do mundo político. Emprego uma metodologia diacrônica para análise dos textos e ações intelectuais de Ozamiz, concluindo pela importância em estabelecermos novos marcos de interpretação sobre o relevante papel da imprensa católica na definição e construção de valores sociais.

Palavras chave: Francisco Ozamiz; Imprensa católica; Revista Ave Maria; Intelectuais católicos.

ABSTRACT: The paper partially analyzes and describes the intellectual trajectory of the Claretian priest Francisco Ozamiz between the years 1909-1929, within the catholic Ave Maria magazine, published in São Paulo, but nationwide. Ozamiz actions towards the project of vitalization of the Catholic press are associated to a significant demand of the Catholic Church in Brazil beginning at the end of the XIX century till the two first decades of the XX century: to expand the influence of the catholic press, establish an effective and critic agenda against the Laic State, making it to reach the field of competition with other religious denominations as well as the political world sphere. Employment a diachronic methodology for the analysis of texts and intellectual actions of Ozamiz, concluding the importance of establish new frameworks of interpretation on the role of the Catholic press in defining and building social values.

Keywords: Francisco Ozamiz; Catholic press; Ave Maria Magazine; Catholic intellectuals.. 


\section{Introdução}

Este artigo discute o papel do padre claretiano Francisco Ozamiz à frente das polêmicas desencadeadas pela revista mariana Ave Maria durante as décadas de 1910 e 1920 sobre o desenvolvimento da imprensa católica e as relações com o Estado laico. Tais polêmicas nos remetem a uma época na qual as publicações católicas passaram a ter difusão mais frequente, além de desempenharem importante função como peças de propaganda religiosa alguns anos depois da separação entre Estado e Igreja no Brasil. A Igreja buscava superar o relativo descrédito de que era alvo durante o Império, e como refere o clássico estudo de Gueiros Vieira (1980, p. 27), o uso e o abuso do direito de padroado da Coroa enfraqueceu ainda mais a independência da Igreja, em certa medida, subserviente ao governo em troca de cargos públicos.

Contudo, a partir do ingresso mais acentuado no país de ordens religiosas europeias, entre finais do século XIX e a década de 1920, a Igreja nacional, através de uma ação combinada de hierarquias, laicato e congregações tratou de expressar projetos que impulsionassem a difusão da "boa imprensa", sendo esta a consigna ampla e norteadora desse projeto. Tal demanda, com efeito, era pronunciada pelo menos desde a emblemática Pastoral Coletiva do Episcopado Brasileiro de 1890, quando os bispos pleitearam uma atitude mais corajosa dos católicos quanto ao trabalho de proselitismo e investimento em meios de comunicação social. Em um dos seus trechos de maior significado, a Pastoral Coletiva insistia em que o amor dos fieis pela Igreja traduzir-seia no empenho de cada católico "na difusão da imprensa católica como um meio de atalhar quanto possível os estragos da imprensa ímpia" (Pastoral Coletiva, 1890, p. 75).

Assim, um dos debates eclesiásticos que persistiu nesse contexto e avançou para as décadas subsequentes girava em torno da criação de estratégias operacionais que garantissem a expansão da imprensa católica diante de adversários como: protestantes, espíritas, políticos anticlericais e imprensa laica e, a um só tempo, constituíssem a "boa imprensa" em lugar que freasse o acelerado processo de secularização em curso. ${ }^{1} \mathrm{O}$ movimento de expansão da imprensa católica tornou-se, desde então, um dispositivo correspondente às aspirações da agenda político-organizacional da Igreja, dando forma e contribuindo para a árdua consolidação de sua autonomia institucional. Para explicitar

\footnotetext{
1 Secularização entendida nos termos de Peter Berger, como a perda do caráter extraordinário que pode haver em certos atos da vida cotidiana, isto é, processo descontínuo e tensional em que se passa a conceber os acontecimentos como puramente profanos (BERGER, 2004, p. 39).
} 
as questões que atravessam esta reflexão associei três ordens de problema que, por sua vez, estão intrinsecamente ligados ao desenvolvimento da imprensa católica nos primeiros anos do século XX: 1) a definição de uma tipologia operativa que dê clareza ao significado de imprensa mariana de matriz popular; 2) se propagandistas católicos que escrevem/escreviam para publicações católicas populares podem ser considerados como "intelectuais", e, sendo este o caso; 3 ) compreender como o "intelectual católico" Francisco Ozamiz, personagem fundamental no interior do debate que proponho, movimentou-se nesse território de produção de sentidos. Tomo como principal fonte para as minhas argumentações um delimitado âmbito de publicações que o padre Francisco Ozamiz legou para a longeva revista Ave Maria, fundada por leigos em 1898 na cidade de São Paulo, e administrada pelos padres da Congregação dos Filhos do Coração de Maria (CMF) a partir de 1899. A revista Ave Maria circula regularmente até os dias de hoje.

\section{A revista Ave Maria: uma proposta de tipologia para a imprensa católica popular}

Sob diferentes enfoques teóricos e metodológicos, os estudos sobre a imprensa católica no Brasil têm recebido frequente atenção de investigadores acadêmicos inquietados com as possibilidades de análise e a polissemia discursiva dessa vertente da comunicação social. ${ }^{2}$ A trajetória da revista mariana Ave Maria é, neste sentido, emblemática em razão da persistência histórica e do prestígio angariado junto aos seus milhares de assinantes. A publicação surgiu em 1898 na cidade de São Paulo, e no ano seguinte passou a ser administrada pela Congregação dos Filhos do Coração de Maria (CMF). A ordem dos claretianos, como é popularmente conhecida, foi fundada na Espanha em 16 de julho de 1849 pelo padre catalão Antonio Maria Claret. A ordem foi criada em um momento relativamente desfavorável para a Igreja católica, e respondeu a um traço bem característico da orientação política do longo pontificado de Pio IX (1846-1878), quanto a incentivar o aparecimento de novas congregações religiosas e a recuperar as antigas. ${ }^{3}$ Essa atitude da Igreja visava, sobretudo, combater as ideologias

\footnotetext{
2 Estes múltiplos enfoques podem ser recordados aqui nos seguintes trabalhos, que, evidentemente não esgotam o tema: ALMEIDA (2002); KLAUCK (2009); DALMOLIN (2012); GONÇALVES (2012).

3 Para o caso brasileiro, Azzi (1983, p. 85-86) reconhece que a República abriu caminho para a restauração das velhas ordens em extinção e para a entrada desimpedida das novas congregações masculinas e femininas: "Foram anos cruciais para a vida religiosa no Brasil onde, praticamente, uma
} 
do mundo moderno - o liberalismo em especial - guarnecido por milícias católicas que dariam ancoragem ao espectro doutrinário da Sé Romana. ${ }^{4}$ Portanto, parece que o florescimento da ordem é correspondente também ao contexto de afirmação do que Martínez (2005, p. 3) denominou de tensão entre o poder pontifício e o apogeu do racionalismo-imanentista-secularizante, forjado, como é comum avaliar, a partir de uma ruptura proposta pelas doutrinas elaboradas desde a revolução francesa.

Atento a essa atmosfera de tensões políticas entre o liberalismo e o catolicismo, Claret, exímio pregador e inovador dos métodos de propaganda católica, celebrizou-se pelo empenho, e evidente êxito alcançado na expansão da imprensa católica de matriz popular. O missionário espanhol foi um dos primeiros a perceber, em meados do século XIX, a amplitude mais profunda que podia ter a palavra escrita sobre a falada, e soube combinar as duplas vantagens oferecidas pela imprensa e a predicação. Entre os anos de 1847 e 1848, portanto, antes da fundação da ordem dos claretianos, Claret inaugurava a Hermandad espiritual de Buenos libros e a Librería Religiosa em Barcelona, multiplicando vocações apostólicas: missionário, escritor, pregador, administrador. Essas características sobressaem no investimento de Claret na massificação da imprensa católica, pela qual procurava-se persuadir o fiel à leitura dos “bons livros”, ou, converter pessoas sem a necessidade de sua presença na Igreja. O religioso destacou em sua Autobiografia que:

Uno de los medios que la experiencia me ha enseñado ser más poderoso para el bien es la imprenta, así como es el arma más poderosa para el mal cuando se abusa de ella. Por medio de la imprenta se dan a luz tantos libros buenos y hojas sueltas, que es para alabar a Dios. No todos quieren o no pueden oir la divina palabra, pero todos puden leer $\mathrm{u}$ oir leer un buen libro; no todos pueden ir a la Iglesia para oir la divina palabra, pero el libro irá a su casa; el predicador no siempre está dispuesto a repetir lo mismo; que en él poco o mucho, que lean y lo dejen una u mil veces, no se ofende por esto; siempre lo encuentra lo mismo, siempre se acomoda a la voluntad del lector. (Claret, 1951, p. 158-159).

Biógrafos de Claret como Papàsogli e Stano (1983, p. 183-185) reafirmaram a eficiência do padre espanhol na administração da imprensa católica. No primeiro ano de atividade, a Librería Religiosa ofereceu ao público cento e vinte mil volumes dos

tradição de vida religiosa se extinguia e outra nascia com novo vigor”.

4 Roger Aubert (1978, p. 839) recorda que logo após a sua eleição em 1846, Pio IX criou uma comissão de cardeais com o encargo de cuidar da restauração das ordens religiosas nos países em que as mesmas haviam se envolvido em distúrbios nos enfrentamentos com as políticas liberais. 
chamados avisos, catecismos e livros de oração. Ao final de 1849, a sede da Librería foi transferida para a bem reputada Via Aviño de Barcelona, tendo adquirido em Paris a mais perfeita rotativa de impressão existente naquele tempo. Em 1850 foram duzentos mil volumes distribuídos e nos próximos dezenove anos de funcionamento da Librería os volumes distribuídos ascenderam à cifra de nove milhões e quinhentos e sessenta mil.

Esse legado de eficiência pastoral e administrativa repercutiu na realização de uma tarefa de grande importância para a congregação quando os primeiros padres claretianos desembarcaram no Brasil em 19 de novembro de 1895: a necessidade de investir na difusão de impressos católicos e impulsionar práticas missionárias sob um duplo respaldo: o congregacional e o hierárquico. No ano de 1899 assumiram o controle da política editorial e de todos os encargos inerentes ao processo produtivo da revista Ave Maria: propaganda, redação, censura, assinaturas, distribuição. A mudança administrativa esteve associada ao aparecimento, em agosto de 1899, da Arquiconfraria do Coração de Maria na capital paulista, e mais especificamente, à implantação de políticas operacionais pelos padres da congregação em busca de novas dinâmicas no funcionamento da revista, após a superação de sucessivas crises que colocaram em risco sua existência. Mas como caracterizar a revista Ave Maria na tipologia de publicação católica popular?

É fundamental que uma publicação católica popular produza sensibilidades para difusão de suas mensagens, e que isso contribua para tornar eficaz o nexo afetivo entre o catolicismo e o mundo social. Nesse sentido, Marcucci e Rum entendem a imprensa mariana como um instrumento de comunicação de massas, e numa acepção mais vasta, sua produção deve abranger setores especializados. Os autores estabelecem para a imprensa católica três categorias: 1) publicações científicas, editadas por academias, faculdades e sociedades mariológicas com caráter internacional; 2) publicações pastorais, dirigidas aos agentes de pastoral com o intuito de oferecer subsídios e estudos para promover a catequese e a pastoral mariana; 3) publicações populares: fenômeno que remonta aos últimos decênios do século XIX, como é o caso da revista Ave Maria. As revistas ou boletins marianos populares são editados em geral por santuários, congregações ou associações marianas. O sensível, em uma publicação mariana popular está relacionado ao culto do coração de Maria, porque é a partir dessa representação que 
Marcucci e Rum observam o quão amplo é o fenômeno mariano: “A figura de Maria em si e por si traz um apelo profundo e difuso" certamente agregado à expressão feminina e, mais ainda, à expressão materna que delineia: "É uma realidade não codificada, que talvez fique abaixo do limiar do consciente, mas que é cheia de grande energia emotiva" (Marcucci e Rum, 1995, p. 621).

Um exemplo flagrante de tal aspecto é evidenciado pela revista Ave Maria quanto à exposição didática sobre o o dever da hiperdulia, a correta e singular forma de prestar culto ao coração de Maria:

A hiperdulia é o culto que se deve ao Coração de Maria. O culto dá-se a alguma pessoa para testemunhar alguma excelência que nela há. Mas a Virgem soberana e seu puríssimo coração encerram excelências supremas como são todas consequentes à divina maternidade. (...) Este culto chama-se hiperdulia, e é superior ao que tributamos a todos os santos e anjos; e ainda especificamente distinto. E a razão é a dignidade da divina maternidade, tão alta, tão excelsa e tão divina que basta de per si para colocar a Virgem Senhora Nossa acima de todas as demais criaturas, santos e anjos (Ave Maria, 1914, p. 130).

$\mathrm{Na}$ apresentação técnica ao leitor, a Ave Maria obedecia aos padrões tipológicos consagrados em toda publicação mariana popular, e, geralmente acompanhava práticas comuns ao periodismo católico de início do século XX no Brasil: folhas soltas, in folio, aqui, também seguindo a tradição das hojas sueltas conforme o modelo propugnado pelo padre Claret no século XIX; formato $18 \times 24 \mathrm{~cm}$, média de dezesseis páginas por edição, ilustrações com personalidades e símbolos católicos, ofertas de produtos religiosos como rosários, catecismos, breviários, política ostensiva de assinaturas familiares, ${ }^{5}$ frequência semanal nas três primeiras décadas do século XX. Sua linha editorial foi intensamente marcada pela polêmica com os "inimigos do catolicismo". Protestantismo, espiritismo, maçonaria, liberalismo, anarquismo, socialismo, e, imediatamente após a revolução russa, e com redobrado ânimo, o comunismo, foram os sistemas e práticas julgados como dissolutos, falsas crenças e ideologias heréticas que repudiavam as leis naturais, e pelas quais seus fautores deviam prostrar-se em penitência caso não aderissem ao catolicismo. Em tal perspectiva de intransigentismo a inexistência de soluções reformistas ou conciliadoras marcou a tônica da revista Ave

\footnotetext{
5 No artigo "O Vigésimo quinto aniversário da Ave Maria" publicado em 26 de maio de 1923, edição n. 20, o padre claretiano Luiz Salamero afirmava que a Ave Maria superava "inumeráveis folhas e revistas congêneres que com ela não se comparam quanto à duração e antiguidade e à extensíssima difusão de seus vinte e dois mil e mais assinantes" (1923, p. 290).
} 
Maria nessas duas primeiras décadas, e, principalmente, deu ensejo a um campo de disputas políticas e polêmicas que ajudaram a projetar a liderança de seus propagandistas, ou, seus "intelectuais" mais assíduos; em especial, o padre Francisco Ozamiz. As possibilidades abertas pelo universo construído na Ave Maria no campo da propaganda e proselitismo religioso nos levam a indagar se o emprego de uma categoria polissêmica como a de "intelectual" é suficientemente operativo para compreendermos o modo de ação pelo qual materializou-se a política editorial da revista, mas também se esta ação contribuiu para conferir ou reafirmar uma identidade a publicações católicas populares como a Ave Maria.

\section{Um cosmos sagrado: publicações católicas como espaço e viveiro de intelectuais}

Qual a pertinência em definir como intelectuais certa camada de indivíduos que pensou, interpretou e escreveu sobre as mais diversas realidades para uma revista católica com o perfil da Ave Maria? Se a questão é formulada, por exemplo, à luz das reflexões de Norberto Bobbio, até que ponto existe uma definição restritiva quanto à natureza e função do intelectual? Um provedor de ideias ou o indivíduo que não negligencia a crítica social, emite juízos morais coerentes a determinados princípios, e, sobretudo, propõe alternativas quanto a modelos de conduta, por si só, satisfaria as condições ou características que o identificam aos homens de cultura. Tais condições, assinala Bobbio (1997, p. 109-110), referem-se a um conjunto de sujeitos específicos, considerados como criadores, portadores, transmissores de ideias; sujeitos a quem se atribui de fato ou de direito a tarefa específica de elaborar e transmitir conhecimentos, teorias, doutrinas, ideologias, concepções de mundo ou simples opiniões.

Assim mesmo, se ainda é problemático caracterizar o homem de ideias das publicações populares católicas como "grande intelectual"; ele pode estar circunscrito em uma camada mais escondida, ou na camada dos "despertadores", tal como a expressão empregada por Jean-François Sirinelli (1996, p. 246). ${ }^{6}$ Porém, não menos imbuído de uma missão pedagógica que marca seu itinerário, e não menos portador de

\footnotetext{
6 O intelectual "despertador", conforme Jean-François Sirinelli (1996, p. 246), é aquele que, sem ser obrigatoriamente conhecido ou sem ter sempre adquirido uma reputação relacionada com seu papel real, representa um fermento para as gerações seguintes. Um despertador, também, pode ocultar dentro de si um outro que o marcou uma geração antes.
} 
argumentos que lhe conferem legitimidade em relação aos seus pares e aos meios em que desempenha seu ofício. É nesse aspecto que o intelectual, retomando Sirinelli, funda reciprocidades nos meios ou engrenagens que favorecem a sua ação, como é o caso das revistas especializadas:

As revistas conferem uma estrutura ao campo intelectual por meio de forças antagônicas de adesão - pelas amizades que as subentendem, as fidelidades que arrebanham e a influência que exercem - e de exclusão - pelas posições tomadas, os debates suscitados, e as cisões advindas. Ao mesmo tempo que um observatório de primeiro plano da sociabilidade de microcosmos intelectuais, elas são aliás um lugar precioso para a análise do movimento de ideias. Em suma, uma revista é antes de tudo um lugar de fermentação intelectual e de relação afetiva, ao mesmo tempo viveiro e espaço de sociabilidade, e pode ser, entre outras abordagens, estudada nesta dupla dimensão (Sirinelli, 1996, p. 248-249).

A noção de uma revista como "viveiro e espaço de sociabilidade" tende a expandir, portanto, o campo de ação do intelectual, e por consequência, os domínios pelos quais transita a sua reflexão. Os sentidos produzidos não visam somente sensibilizar o público católico, mas enquanto grupo organizado, os intelectuais propagandistas de publicações católicas populares projetam um olhar sobre o mundo que visa atingir uma audiência diferenciada e mais ampliada, a partir de um "conjunto de crenças e valores que se firmam como consenso" no interior do grupo (Pinheiro Filho, 2007, p. 33).

Outro argumento que reafirma esses critérios vem do efeito de presença desses intelectuais. Se aqui já operamos a transição dessas noções associando-as ao legado deixado pelo padre claretiano Francisco Ozamiz, é porque esse "intelectual despertador" notabilizou-se pela regularidade temporal, pela constância e espírito missionário pelos quais manteve sua adesão ao projeto da revista Ave Maria e do periodismo católico. Seja na forma de séries de textos com o estudo de assuntos específicos, seja no formato de crônicas cotidianas que deixavam escapar ao leitor as inquietações do seu tempo; a possível receptividade positiva aos textos de Ozamiz ficou evidenciada pelo largo período de tempo que contribuiu para a revista, contribuição que apenas cessou com a sua morte em 1929. Mesmo assim, a tarefa de Ozamiz representa sob o ponto de vista da religião, o empreendimento em instituir a imprensa católica como um cosmos sagrado, desde que se entenda tal expressão como a qualidade na qual repousam os princípios supremos que governam o mundo. Como destaca Berger (2004, p. 39-40), 
embora as manifestações do sagrado variem muito e escapem à rotina normal do dia a dia, revestindo-se, portanto, de algo extraordinário e potencialmente perigoso; esses perigos podem ser domesticados e sua força ser reapropriada para as necessidades cotidianas. A imprensa católica é, assim, um cosmos que, ao mesmo tempo, transcende e inclui o homem porque realiza, minimamente, a tarefa de ordenar a experiência humana na realidade através da linguagem, mas também porque produz significados extraordinários e sobrenaturais.

\section{Francisco Ozamiz: um intelectual católico e seu tempo}

A edição 48 da revista Ave Maria de 30 de novembro de 1929 provavelmente surpreendeu suas trinta mil famílias assinantes. Ela noticiava que Francisco Ozamiz morrera, aos 55 anos, no dia 26 de novembro, às duas horas da manhã na cidade de São Paulo (Ave Maria, 1929, p. 900).

Francisco Ozamiz era espanhol. Nasceu em Guernica no dia 2 de abril de 1874 e fez seus estudos em teologia e filosofia na Universidade de Cervera, recebendo a sagrada ordem do sacerdócio em Santo Domingo de la Calzada. Em 1897 chegou ao Brasil e passou a ocupar lugares de destaque no governo da província claretiana. Além de exercer o cargo-chefe das importantes residências de Campinas, Rio de Janeiro e São Paulo, Ozamiz publicou, ao menos, quatro livros: Bandeirantes da Imprensa; Princípios de Educação; Modernos e não modernistas; A Paz do Papa. Foi diretor da revista Ave Maria e fundou as publicações claretianas "Lourdes" em Belo Horizonte; "A Paz" no Rio de Janeiro, e "A Verdade" em Campinas.

Quando requisitado para a nova casa provincial dos claretianos em Belo Horizonte, e depois, ao final da primeira década do século XX quando era transferido para Campinas, o principal trabalho de Ozamiz concentrou-se na imprensa e no ensino. Em 1926 foi enviado para assumir a administração das Prelazias de São José do Alto Tocantins e da Ilha do Bananal, e costumava publicar com regularidade notícias sobre a obra missionária que desenvolvia na região. O necrológio publicado na Ave Maria em sua edição 48 de 26 de novembro de 1929 sob o título "Última Hora" ressaltava:

Devido aos grandes esforços na sua santa missão, contraiu a insidiosa moléstia que o fez retornar a São Paulo, onde, há cerca de um ano, encontrava-se em tratamento. Não conseguiu, infelizmente vencê-la, falecendo o [sic] dia 26 em quarto particular da Santa Casa de 
Misericórdia. Com o desaparecimento de M. Francisco Ozamiz a Congregação dos Filhos do Coração de Maria perde um dos seus mais distintos e virtuosos filhos, a Igreja católica lamenta a morte de um grande auxiliar, que viveu para a sua glória e o Brasil chorará a falta de um bom que trabalhou por ele e se sacrificou em longos anos de apostolado. Descanse em paz, o querido irmão. (Ave Maria, 1929, p. 900-901).

Missionário, escritor, diretor de revistas, conversor de pecadores, professor, jornalista, enfim, intelectual, Ozamiz, nas mais de duas décadas em que esteve regularmente envolvido com a imprensa católica, foi um exímio articulador de ideias apropriadas a uma publicação como a Ave Maria, que requeria textos ágeis, polêmicos e provocadores, e que provavelmente conduziam o leitor a pelo menos dois caminhos: ou ao imediato consenso, ou ao repúdio, mas nunca à indiferença.

De acordo com Bencostta (1999, p. 173), entre 1909 e 1911 Ozamiz tornara-se assessor e colaborador de Dom João Batista Corrêa Nery, bispo de Campinas, e esta aproximação impulsionou uma militância altamente organizada. Atuava na pastoral, na missão, no proselitismo antimoderno e antiprotestante. Como seu meio fundamental de enunciação foi a imprensa, proponho destacar três facetas do trabalho de Ozamiz que são complementares e indicam a importância que o periodismo adquiriu para sua predicação: o papel da mulher na difusão do periodismo católico, a relação entre o jornalismo católico e os erros modernos, a necessidade de afirmar uma teologia política que pudesse intervir na relação entre Estado, Igreja e sociedade.

Para Francisco Ozamiz, a psicologia da mulher era a mais adequada no trabalho abrangente de propaganda da imprensa católica. Traço característico dessa personalidade era a "impessoalidade" pela qual a mulher encarnava as ideias, daí porque ela seria dotada de um organismo mais vivo e de um espírito mais ativo para concretizar rapidamente ideias em atos. Também mais propícia em reter lembranças, imagens, sensações, sentimentos, emoções e hábitos, embora sem uma concepção lógica tão profunda quanto o homem, a mulher era o meio de formação, de auxílio pecuniário e de propaganda mais intensa, surda e pacífica. A impiedade moderna inflava a emancipação da mulher porque sabia que ela emancipada "é a ideia feita carne, feita sentimento, feita imagem, feita sensível, feita ato, porque é rica em elementos psicológicos”. Por isso, a necessidade de resgatá-la desses perigos e redirecionar suas energias físicas e mentais para obra mais elevada conscientizando-a do seu papel conjuntivo ao destino da Igreja: 
Um dos campos onde se deixa sentir mais do que em outros redutos da atividade católico social a influência salutar e benfazeja da mulher é na Boa Imprensa. A mulher ainda nos ouve, a mulher comunga nos princípios da fé cristã, a mulher ainda não abandonou o caminho traçado pela religião. Mas porque não aproveitamos mais esse elemento importante, essa sombra que o nosso século respeita, essa gloriosa conquistadora da estética, da elegância e do bom gosto? Julgamos que é desnecessária a ação da mulher na imprensa? Julgamos que nos desprezará neste pedido e não responderá com seu heroísmo, sempre provado, nesta tremenda luta que na arena da imprensa se trava entre os filhos de Deus e os filhos da Besta? Ah! Não. A mulher cristã reconhece que foi a Igreja quem lhe arrancou das trevas do paganismo, sabe que foi a Igreja quem derreteu as algemas da sua escravidão, conhece que foi a Igreja quem a emancipou antes das falsas emancipações modernas, dando-lhe a honra do lar, garantindo-lhe o direito da liberdade de consciência e cingindo-lhe a fronte com o diadema de Mãe e Esposa e ungindo-lhe com os encantos e respeitos castíssimos de Filha, menina e moça, luz e aroma, inocência e beleza, sorrisos e alegrias, promessas e esperanças. Peçamos do coração da mulher uma cooperação para a Boa Imprensa. Quando a impiedade gritar, essa é a religião das mulheres! Nós altivos respondamos, é a religião das mulheres, porque é a religião da verdade, a religião de Deus... (Ozamiz, 1909, p. 710). ${ }^{7}$

A mulher, esse papel em branco antes da ação da Igreja, seria recrutada obedecendo aos requisitos da discrição, prudência, harmonia, conselho e dedicação. Ozamiz percebia, evidentemente, a maior presença feminina no espaço urbano que resultou, de forma gradativa, em novas atitudes comportamentais fosse na moda ou no mundo do trabalho. Desse modo, insistia com seus leitores e leitoras que predominasse nas ações femininas a verdadeira essência da católica: ser Esposa, Mãe, e Filha, e trazer em si certa persuasão ao lidar, respectivamente, com o marido, filho e pai. Assim: "A Esposa sem defender os direitos que as sufragistas e outras variedades da mulher emancipada propugnam, pode ainda se impor ao espírito do seu marido. Procure para o seu Esposo indiferente ou ímpio, jornais sensatos, imparciais, católicos” (Ozamiz, 1909, p. 775$){ }^{8}$

Outro estágio da ação da mulher pela boa imprensa passava pela sua função de censora dos textos contidos nos jornais não católicos. Mas tal função somente se configurava por uma radicalização de atitude: “A mulher pode boicotar a imprensa

7 OZAMIZ, Francisco, pe. A missão e os missionários do jornalismo XVII - A mulher e a imprensa. Revista Ave Maria, São Paulo, n. 45, p. 710-711, 1909. A partir desta primeira citação aos artigos de Ozamiz, adoto como critério o emprego de referências completas aos textos do padre mencionando-as em nota de rodapé.

8 OZAMIZ, Francisco, pe. A missão e os missionários do jornalismo XX - A mulher e a imprensa. Revista Ave Maria, São Paulo, n. 49, p. 775-776, 1909. 
indígena, pornográfica ou herética" (Ozamiz, 1909, p. 788). ${ }^{9} \mathrm{O}$ padre claretiano acreditava com inadvertida simplicidade que se uma demanda feminina organizada, um exército católico de saias, manifestasse de público o seu desagrado por jornais anticlericais, em pouco tempo eles sumiriam de circulação. Mas somente o boicote seria algo limitado. Além dele, eram aconselhados a oração para fortalecer a luta pela destruição das más leituras, a obrigatoriedade de assinatura de um jornal católico, a propaganda, a procura por anunciantes, e a espontaneidade para fornecer donativos e presentes às folhas católicas (Ozamiz, 1909, p. 806). ${ }^{10}$ Nesse sentido, Ozamiz operou em duas frentes: os artigos na Ave Maria, e o incessante trabalho junto às cooperadoras femininas. Correlata à construção dos argumentos sobre a mulher e a imprensa católica, o padre havia fundado em Campinas a "Associação das Cooperadoras de São Miguel”, na qual exercia o cargo de diretor espiritual, sendo o restante da direção da entidade composto exclusivamente por mulheres. A finalidade da instituição consistia na distribuição gratuita "do pão da verdade nas camadas falhas do conhecimento que é o alimento de nosso espírito" (Ozamiz, 1909, p. 806). ${ }^{11}$ A experiência de Campinas inflamou os ânimos de Ozamiz para que dela surgissem organizações análogas e plenas de símbolos e distintivos que fizessem remissão a São Miguel, o grande protetor da Igreja e aquele que no Apocalipse (12: 7-9) lidera os exércitos de Deus - cuja metáfora aqui talvez possa ser a imprensa católica - contra as forças de Satã - cuja metáfora aqui talvez possa ser a imprensa ímpia - e os derrota durante a guerra no céu (GARMUS, 1982, p. 1461). ${ }^{12}$

O segundo tema proposto gira em torno do debate doutrinário sobre as heresias modernas, cuja origem situa-se possivelmente na luta contra o modernismo católico impulsionada durante o pontificado de Pio X (1903-1914). O modernismo refere-se a um grupo de tendências renovadoras que emergiu na Igreja no início do século XX, caracterizando-se por reunir um temário de ideias heterogêneas e agrupar aspectos

\footnotetext{
9 OZAMIZ, Francisco, pe. A missão e os missionários do jornalismo XXI - A mulher e a imprensa. Revista Ave Maria, São Paulo, n. 50, p. 788-789, 1909.

10 OZAMIZ, Francisco, pe. A missão e os missionários do jornalismo XXII - A mulher e a imprensa. Revista Ave Maria, São Paulo, n. 51, p. 806-807, 1909.

11 OZAMIZ, Francisco, pe. A missão e os missionários do jornalismo XXII - A mulher e a imprensa. Revista Ave Maria, São Paulo, n. 51, p. 806-807, 1909.

12 "Houve uma batalha no céu: Miguel e seus anjos tiveram de combater o dragão. O dragão e seus anjos combateram mas não puderam vencer e não houve mais um lugar para eles no céu. O grande dragão, a antiga serpente, chamada diabo e Satanás, que seduz o mundo todo, foi então precipitado para a terra e com ele os seus anjos" (GARMUS, 1982, p. 1461).
} 
difusos nos países em que se manifestou com maior impacto, como França e Itália. A exegese bíblica, o debate sobre os limites da filosofia tomista e sobre a autoridade do magistério eclesiástico, foram algumas das inúmeras reflexões que perpassaram o discurso dos teólogos modernistas. Condenados em 1907 pela encíclica Pascendi e pelo decreto Lamentabili de Pio X, por sua ousadia no emprego dos métodos históricocríticos quanto à interpretação escriturística, alguns modernistas como Alfred Loisy na França, Romolo Murri na Itália ou George Tyrrel na Irlanda sofreram a excomunhão e afastaram-se das cátedras de universidades católicas, sem nunca abdicarem, entretanto, das ideias que julgavam como uma exigência filosófica e histórica para a renovação da Igreja e de seu efetivo ingresso na sociedade moderna. ${ }^{13}$

Ozamiz replicará uma sensibilidade antimodernista como demanda obrigatória do jornalismo católico. Para ele, o primeiro dever do jornalista católico é que fosse ortodoxo na doutrina, fugindo das aparências da heresia. No período histórico em que se vivia era muito fácil cair nos laços de alguma espécie de modernismo científico ou social: "O modernismo, porém, é a síntese de todas as heresias, consoante à expressão do Papa Pio X na Encíclica Pascendi” (Ozamiz, 1911, p. 24). ${ }^{14}$

No início de 1914, Ozamiz voltaria a insistir na questão recorrendo ao conceito de "heresia sintética" para qualificar o modernismo católico. O termo era empregado para todas as formas de pensamento que pretendiam adaptar as doutrinas e romper o monólito eclesial com "consciência e a filosofia da época, embora este meio ambiente esteja saturado de princípios deletérios"; assim, os modernistas intuíram que a Igreja “devia viver num amplexo fraternal com o agnosticismo e a imanência vital do voluntarismo" (Ozamiz, 1914, p. 52). ${ }^{15}$ O padre construiu um paralelo entre as prescrições da Pascendi e a representação sobre a imprensa: o erro poderia introduzir-se em disfarces da verdade. Quem não fosse um profissional jornalista, não poderia assuntar aleatoriamente e à sua vontade. Em outros termos, o teólogo modernista que desejava arrojar-se em campos que os limites impostos pela disciplina eclesiástica não permitiam alcançar, equivalia a um mau jornalista que podia "conhecer mais ou menos

\footnotetext{
13 Sobre a crise modernista na Igreja católica, além do clássico texto de Émile Poulat (1969), pode-se consultar a excelente abordagem de Maurilio Guasco (2000).

14 OZAMIZ, Francisco, pe. O jornalismo - Normas Diretivas. Revista Ave Maria, São Paulo, n. 2, p. 23-24, 1911.

15 OZAMIZ, Francisco, pe. Apologia do Catolicismo - A história da apologia. Revista Ave Maria, São Paulo, n. 4, p. 52-53, 1914.
} 
as ciências que em horas vagas estudou, mas sempre tem lacunas a preencher, termos equívocos ou ambiguidades que o especialista evita". ${ }^{16}$ Contudo, o modernismo não era algo interno à Igreja, porque as heresias, em sua versão mundana infiltravam-se nas doutrinas políticas, podendo definir a orientação ideológica dos Estados. Ozamiz investiria na formulação de uma teologia política, apresentando como principal alvo de crítica o Estado laico, depositário de antíteses ideológicas: o ultraliberalismo moderno e as doutrinas socialistas.

São reconhecíveis na fala de Ozamiz os usuais argumentos que recusavam a independência legal e ética do Estado em face da legitimidade supramundana da Igreja como o lugar central a oferecer respostas, fundamentos e subsídios teológicos ao ordenamento jurídico das relações sociais. Em "Cartas à Mocidade Acadêmica" o padre claretiano desconstruía a hipótese de autoridade do Estado em definir políticas fora da esfera da religião. Em uma época turbulenta em que reivindicações operárias e avanço das denominações evangélicas aturdiam a maioria católica somente uma ética seria eficaz para sufocar tensões e agregar valores necessários à convivência pacífica entre ricos e pobres, patrões e operários; coexistência "necessária pela justiça da propriedade individual, que é tão sagrada como a própria personalidade" (Ozamiz, 1913, p. 556). ${ }^{17}$ Tal ética viria da dependência recíproca de serviços espirituais e temporais, ou, em outras palavras, de uma aliança entre poder eclesiástico e poder civil. Porém:

Sendo possível, é melhor que a Igreja viva economicamente separada do Estado, porque não parecerá, desta forma, subserviente e como que funcionaria de tesouro público. A união ética que consiste na moral evangélica que há de informar todas as repartições públicas e todas as forças vivas da nação, essa é como uma necessidade da própria higiene social, visto que não se realizará o saneamento moral sem essa informação do espírito evangélico. (Ozamiz, 1913, p. 651, grifos no original). ${ }^{18}$

O amadurecimento das discussões sobre os limites do Estado laico dar-se-á no contexto da revisão constitucional de 1925/1926. ${ }^{19}$ Como destacou Vieira (2007, p.

16 OZAMIZ, Francisco, pe. Apologia do Catolicismo - A história da apologia. Revista Ave Maria, São Paulo, n. 4, p. 52-53, 1914.

17 OZAMIZ, Francisco, pe. Cartas à mocidade acadêmica. Revista Ave Maria, São Paulo, n. 35, p. 555$556,1913$.

18 OZAMIZ, Francisco, pe. Cartas à mocidade acadêmica - harmonias necessárias. Revista Ave Maria, São Paulo, n. 41, p. 651-652, 1913.

19 O salto cronológico na abordagem aos artigos de Ozamiz é justificado pela decisiva preocupação do religioso, entre os anos de 1914 a 1923, com dois projetos que, evidentemente, não estão ao alcance do recorte temático deste artigo. O primeiro refere-se ao seus discursos sobre a apologética católica e aos 
503-504), chegara para a Igreja o momento de passar à ação concreta a favor do reconhecimento público, quando Artur Bernardes apresentou ao Parlamento o anteprojeto de reforma da Constituição de 1891. As chamadas "emendas religiosas" propostas pelo deputado Plínio Marques visavam modificar os parágrafos 6 e 7 do artigo 72. No primeiro, embora a Igreja reconhecesse o ensino leigo; o ensino com caráter obrigatório ministrado nas escolas não excluiria o ensino religioso facultativo. $\mathrm{O}$ outro, acrescentava que, conquanto reconhecesse o catolicismo como a religião do povo brasileiro, em sua quase totalidade, nenhum culto ou Igreja receberia subvenção oficial nem teria relações de dependência ou aliança com o governo da União ou dos Estados.

Mobilizado pela revista Ave Maria para encarnar a causa católica na revisão constitucional, Ozamiz empregou como conexão o auxílio da revista que ajudara a desenvolver. Em longa conferência pronunciada na Legião de São luiz da Mocidade na capital paulista e publicada na Ave Maria, Ozamiz argumentou que o Estado não podia eficientemente cumprir a sua missão de procurar o bem geral sem socorrer-se de princípios certos, de dogmas (Ozamiz, 1925, p. 568). ${ }^{20}$ Ancorando-se na retórica antimodernista, o intelectual claretiano demonizava a "fantasia modernista" afirmando que um agnosticismo social e constitucional imposto pela política reduziria a religião a uma ideia, ou a uma explosão sentimental: “A Religião não é um produto da subconsciência consoante às fantasias do modernismo, a Religião apreende, ela bebe no manancial da Revelação divina que apresenta fatos que não cream”. ${ }^{21}$

Entre final de outubro e início de dezembro de 1925, quando os debates parlamentares acirravam-se, Ozamiz publicou comentários que resultaram em aberta polêmica com o deputado da corrente anticlerical, Basílio de Magalhães. Dirigia uma carta ao deputado e padre Valois de Castro, pela qual assumia uma série de pontos a serem considerados na relação entre Igreja e Estado. Pretendo destacar brevemente dois deles: 1) a neutralidade incolor; 2) a igualdade desigual.

Para Ozamiz a Igreja possuía um direito democrático, robustecido pela prescrição secular e pela conquista da educação, e garantida pela maioria numérica, ética e social. O padre investia contra a neutralidade, "aparentemente incolor" preferida

seus esforços na construção do Templo Votivo Cordimariano em Roma. O segundo está associado a funções administrativas que assumiu tanto em relação à revista Ave Maria, quanto à província claretiana em São Paulo.

20 OZAMIZ, Francisco, pe. O ideal religioso. Revista Ave Maria, São Paulo, n. 36, p. 568-571, 1925.

21 OZAMIZ, Francisco, pe. O ideal religioso. Revista Ave Maria, São Paulo, n. 36, p. 568-571, 1925. 
pelos laicistas da esquerda. Neutralidade religiosa desaguada no campo da sociedade civil só era interessante aos inimigos do catolicismo ou "as seitas que falando muito do Senhor Jesus, preferem estar nestas horas, com os inimigos declarados de Jesus". A neutralidade dogmática não era somente uma proclamação do laicismo intangível, mas um disfarce para os propagandistas anticatólicos, para os destruidores das tradições nacionais:

A Neutralidade pretende chegar à igualdade de todas as religiões. Essa Igualdade é a mais monstruosa Desigualdade. Se a religião católica é a Religião socialmente soberana no Brasil, porque a Soberania política que é o reflexo da Soberania social quer proclamar a sua Igualdade desigual perante as religiões estrangeiras, que não assistiram e não concorreram para o desenvolvimento do País? (Ozamiz, 1925, p. 693). [Grifos no original]. ${ }^{22}$

Com as expectativas da reforma constitucional no que tangia às emendas religiosas frustradas para os católicos, Ozamiz continuou apegando-se ao argumento da obrigatoriedade de o Estado subvencionar o ensino confessional para cuidar dos “direitos dos pais católicos”. Esta era uma reivindicação, segundo o padre, da soberania social sobre a soberania política, e a relação contribuinte/Estado era vista, simplesmente, como "contribuinte católico" /Estado:

Essa soberania social a formam as famílias, cujos direitos na educação dos seus filhos são sagrados. Quando os pais de família pagam os impostos, pagam-nos para instrução dos seus filhos. Ora, se o laicismo intangível sustenta e pratica a ausência total da ideia religiosa, atenta contra os direitos dos pais, é um abuso de confiança. O clero funda escolas com minguados recursos. O Estado dispõe de grandes recursos e meios legais para isolar os esforços particulares (OZAMIZ, 1925, p. 792). ${ }^{23}$

Esta foi uma das derradeiras intervenções políticas de Ozamiz a favor dos direitos da Igreja na revista Ave Maria: "O frade vai para onde a obediência religiosa que professou, lhe ordena" (Ozamiz, 1926, p. 81). ${ }^{24}$ Entre finais de 1926 até novembro de 1928, mês em que dirigiu seu último artigo para publicação na Ave Maria antes da morte, Ozamiz manteve a seção "Echos da Prelazia de S. José do Alto Tocantins", para onde foi enviado em regime de missão, assumindo novas funções. Esta seção passou a

22 OZAMIZ, Francisco, pe. O Catolicismo Social do Brasil. Revista Ave Maria, São Paulo, n. 44, p. 692-693, 1925.

${ }^{23}$ OZAMIZ, Francisco, pe. Ainda as emendas religiosas. Revista Ave Maria, São Paulo, n. 50, p. $792-$ 793, 1925.

24 OZAMIZ, Francisco, pe. Carta-resposta ao Sr. Dr. Basílio de Magalhães. Revista Ave Maria, n. 5, p. 79-82, 1926. 
consistir em comentários gerais a respeito das condições em que sua missão atuava num lugar desprovido, por certo, de estruturas elementares às quais estava habituado nas cidades em que atuou. Mas nada como a fé católica que levava aos sertanejos e aos índios "a grande luz da verdade e as grandes consolações do espírito", sem, claro está, dispensar dos devotos urbanos uma ajuda pecuniária que acelerava a obra religiosa e patriótica do missionário:

Leitores amadíssimos, um pequeno auxílio para as nossas missões de S. José de Tocantins em Goiás. Em S. Paulo, Rua Jaguaribe n. 93, ou caixa postal 615, ou no Rio de Janeiro rua Cardoso n. 54, podemos receber qualquer lembrança vossa como presente do Natal e Ano Bom para as necessidades dos sertanejos e dos queridíssimos índios da Ilha do Bananal, hoje outrossim sob a responsabilidade da Prelazia de S. José dos Tocantins. Espero que no próximo número poderei agradecer algumas esmolas ou donativos que se nos enviem para este fim tão nobre e louvável. O menino Jesus vos põe a bandeja na frente e vos diz: Uma esmola para os sertanejos de S. José de Tocantins e para os pobres índios Javaés da Ilha do Bananal (Ozamiz, 1926, p. 948-949).

\section{Considerações finais}

Embora o conteúdo das reivindicações, as prioridades e âmbitos de luta no discurso de Ozamiz pudessem variar ao longo desse tempo, o núcleo-diretor de sua argumentação era impulsionado por critérios absolutos e categóricos, que os próprios dogmas católicos trataram de sedimentar em seu pensamento.

A crença de Ozamiz, assim como a crença de intelectuais católicos mobilizadores à época, era que o catolicismo constituía-se em elemento de ordem, disciplina social, fundamento para conversão e sacralização do espaço público. Desde 1890, a Igreja católica insistia em não subscrever o pragmatismo político do Estado laico, que concebia valor às doutrinas não pela sua verdade intrínseca, mas unicamente pela utilidade social que delas pudesse extrair. A fé católica, dentro desse entendimento, valia por si mesma e o esforço dos católicos não poderia chegar à extravagância de admitir a religião como uma espécie de mero auxiliar do Estado, uma ferramenta subalterna a quem o Estado recorresse para conter paixões coletivas. O papel da Igreja na ótica de Ozamiz e das hierarquias, era de protagonista.

Ozamiz contribuiu, desde o lugar que ocupava na imprensa católica e na predicação, para encorajar seus leitores a sentirem-se, de fato, como a verdadeira e

25 OZAMIZ, Francisco, pe. Echos da Prelazia de S. José do Alto Tocantins. Revista Ave Maria, São Paulo, n. 51, p. 948-949, 1926. 
única força espiritual. Foi um intelectual militante que almejava formar militantes. Desde essa perspectiva, se o padre claretiano não pode ser perfilado às figuras com uma presumível maior estatura intelectual do que ele, como Jackson de Figueiredo ou Alceu Amoroso Lima, será a seu modo, um ator decisivo que contribuiu por quase três décadas para moldar um sistema de valores.

Por outro lado, a breve análise e os aspectos descritivos que empreendi neste artigo, talvez permitam reconsiderar a existência de articulação entre as dimensões religiosa e política reivindicadas pelos "intelectuais despertadores" da revista Ave Maria, bem como de suas congêneres. A coexistência de ambas as esferas revelou-se nas unidades temáticas que elegi para situar o tema "intelectuais e imprensa católica" como objeto plausível de análise histórica. De maneira que as perspectivas de investigação sobre o papel assumido pela imprensa católica em temporalidades díspares podem mostrar-se especialmente frutíferas. As pesquisas sobre a imprensa católica, assim como o respectivo escrutínio sobre a atuação de seus atores são elementos que podem favorecer abordagens associadas aos seguintes aspectos problematizadores: como a Igreja produziu respostas institucionais a tempos acelerados de informalização e mudança de comportamentos; como a Igreja construiu metáforas e narrativas para enfrentar as "heresias modernas"; como foi capaz de radicalizar sua posição em face das inovações trazidas pelo mundo político e religioso, mas igualmente, por quais modos a Igreja acionou mecanismos simbólicos de reconciliação e transigência para conceber novas fontes de poder social.

\section{Fontes}

Culto ao Coração de Maria. Revista Ave Maria, São Paulo, n. 9, p. 130, 1914.

Última Hora. Revista Ave Maria, São Paulo, n. 48, p. 900-901, 1929.

OZAMIZ, Francisco, pe. A missão e os missionários do jornalismo XVII - A mulher e a imprensa. Revista Ave Maria, São Paulo, n. 45, p. 710-711, 1909.

A missão e os missionários do jornalismo XX - A mulher e a imprensa. Revista Ave Maria, São Paulo, n. 49, p. 775-776, 1909.

A missão e os missionários do jornalismo XXI - A mulher e a imprensa. Revista Ave Maria, São Paulo, n. 50, p. 788-789, 1909. 
A missão e os missionários do jornalismo XXII - A mulher e a imprensa. Revista Ave Maria, São Paulo, n. 51, p. 806-807, 1909. $\overline{24,1911 .}$

O jornalismo - Normas Diretivas. Revista Ave Maria, São Paulo, n. 2, p. 23Cartas à mocidade acadêmica. Revista Ave Maria, São Paulo, n. 35, p. 555$556,1913$.

Cartas à mocidade acadêmica - harmonias necessárias. Revista Ave Maria, São Paulo, n. 41, p. 651-652, 1913.

Apologia do Catolicismo - A história da apologia. Revista Ave Maria, São Paulo, n. 4, p. 52-53, 1914.

O ideal religioso. Revista Ave Maria, São Paulo, n. 36, p. 568-571, 1925. $693,1925$.

O Catolicismo Social do Brasil. Revista Ave Maria, São Paulo, n. 44, p. 6921925.

Ainda as emendas religiosas. Revista Ave Maria, São Paulo, n. 50, p. 792-793,

Carta-resposta ao Sr. Dr. Basílio de Magalhães. Revista Ave Maria, n. 5, p. 7982, 1926.

Echos da Prelazia de S. José do Alto Tocantins. Revista Ave Maria, São Paulo, n. 51, p. 948-949, 1926.

Pastoral Coletiva do Episcopado Brasileiro ao Clero e aos Fiéis do Brasil. São Paulo: Typographia Jorge Seckler \& Comp., 1890.

SALAMERO, Luiz, pe. O Vigésimo quinto aniversário da Ave Maria. Revista Ave Maria, São Paulo, n. 20, p. 290-291, 1923.

\section{Referências}

ALMEIDA, Cláudio A. Meios de comunicação católicos na construção de uma ordem autoritária, (1907-1937). 2002. Tese (Doutorado em História). Faculdade de Filosofia, Letras e Ciências Humanas, Universidade de São Paulo, São Paulo.

AUBERT, Roger. Luz y sombras de la vitalidad católica. In: JEDIN, Hubert. (Dir.). Manual de la Historia de la Iglesia. Tomo Septimo: La Iglesia entre la Revolución y la Restauración. Barcelona: Herder, 1978, p. 838-845.

AZZI, Riolando. A vida religiosa no Brasil. Enfoques históricos. São Paulo: Paulinas, 1983. 
BEnCOSTTA, Marcus L. Igreja e Poder em São Paulo: D. João Batista Corrêa Nery e a Romanização do Catolicismo Brasileiro (1908-1920). 1999. Tese (Doutorado em História), Faculdade de Filosofia, Letras e Ciências Humanas, Universidade de São Paulo, São Paulo.

BERGER, Peter L. O dossel sagrado: elementos para uma teoria sociológica da religião. Trad. José Carlos Barcellos. São Paulo: Paulus, 2004.

BOBBIO, Norberto. Os intelectuais e o poder: dúvidas e opções dos homens de cultura na sociedade contemporânea. Trad. Marco Aurélio Nogueira. São Paulo: Unesp, 1997.

CLARET, Antonio Maria. Autobiografía. Madrid: Editorial Coculsa, 1951.

DALMOLIN, Aline. O discurso sobre aborto em revistas católicas brasileiras: Rainha e Família Cristã (1980-1990). 2012. Tese (Doutorado em Ciências da Comunicação), UNISINOS, São Leopoldo.

GARMUS, Ludovico. (Coord.). Bíblia Sagrada. Trad. Domingos Zamagna et al. 33. Ed. Petrópolis: Vozes, 1982.

GONÇALVES, Marcos. As tentações integristas. Um estudo sobre imprensa católica, política e catolicismo no Brasil (1908-1937). Curitiba: Editora CRV, 2012.

GUASCO, Maurilio. El modernismo. Los hechos, las ideas, los personajes. Bilbao: Desclée de Brouwer, 2000.

GUEIROS VIEIRA, David. O Protestantismo, a Maçonaria e a Questão Religiosa no Brasil. 2. Ed. Brasília: Editora da UnB, 1980.

KLAUCK, Samuel. O apostolado da imprensa: a revista St. Paulus-Blatt como instrumento de informação, formação e catequese no Rio Grande do Sul (19121934). 2009. Tese (Doutorado em História), Programa de Pós-Graduação em História, Universidade Federal do Paraná, Curitiba.

MARCUCCI, Don Azzo; RUM, Andrea. Imprensa Mariana. In: FIORES, Stefano de; MEO, Salvatore. (Dir.). Dicionário de Mariologia. Trad. Álvaro A. Cunha et al. São Paulo: Paulus, 1995, p. 620-625.

MARTÍNEZ, Pedro D. El beato Pio IX clarividente intérprete de su época. DIVINITAS - Rivista Internazionale di Ricerca e di Critica Teologica, Cittá del Vaticano, Anno XLVIII, n. 1, p. 3-15, 2005.

PAPÀSOGLI, Giorgio; STANO, Franco. Antonio Claret: l'uomo che sfidò l'impossible. Cittá del Vaticano: Libreria Editrice Vaticana, 1983.

PINHEIRO FILHO, Fernando A. A invenção da ordem. Intelectuais católicos no Brasil. In: Tempo Social, Revista de Sociologia da USP, v. 19, n. 1, p. 33-49, 2007. 
POULAT, Émile. Intégrisme et catholicisme intégral: un réseau secret international antimodernista: la "Sapinière" (1909-1921). Paris: Casterman, 1969.

SIRINELLI, Jean-François. Os Intelectuais. In: RÉMOND, Réne. (Org.). Por uma história política. Trad. Vera Rocha. Rio de Janeiro: Editora da UFRJ, 1996, p. 231269.

VIEIRA, Dilermando R. O processo de reforma e reorganização da Igreja no Brasil (1844-1926). Aparecida: Editora Santuário, 2007.

Recebido: $28 / 04 / 2016$

Received: 04/28/2016

Aprovado: $30 / 05 / 2016$

Approved: 05/30/2016 